\title{
EFFECT OF LITTER TREATMENT WITH PROBIOTIC BACTERIA ON AMMONIA REDUCTION IN COMMERCIAL BROILER FARM
}

\author{
Andrea Pezzuolo, Cristina Sartori, Evelin Vigato, Stefano Guercini \\ University of Padova, Italy \\ andrea.pezzuolo@unipd.it,
}

\begin{abstract}
The impact of aerial emissions from animal farms has yet to be fully solved and is a source of much controversy and debate. In particular, a major issue with poultry litter is the loss of nitrogen as ammonia $\left(\mathrm{NH}_{3}\right)$ due to microbial mineralization of urea and uric acid, which represent up to $80 \%$ of the total nitrogen in litter. Both the concentration and exposure time of birds to ammonia may have negative influence on the health both of birds and workers, such as tracheal irritation, eye damage, decreased feed efficiency and mortality. Thus, reduction in ammonia emissions is important. In the last years, physical, chemical and biological methods were often used, in particular, biological control has been studied by many researchers. Alongside the reduction of the nitrogen content in food, proper management of litter is also essential with regard to the choice of materials, its care during the growth of animals, the use of additives. Among the latter, particularly promising appears to be the use of microbial additives to litter, feed or drinking water. The aim of this research is to evaluate the effect of probiotic bacteria (PB)in the reduction of ammonia emissions from a commercial farm in Veneto (northern Italy).Preliminary results obtained from the use of PB in the litter have shown a reduction of ammonia emissions of at least $35 \%$ compared to a comparison thesis, without treatment.
\end{abstract}

Keywords: poultry, litter, ammonia emission, air quality, probiotic bacteria.

\section{Introduction}

Livestock farming plays a critical role in global food production. At the same time, livestock farming systems are a major source of trace gases contributing to atmospheric pollution locally and globally [1-3] and the problem of aerial emissions from animal farms has yet to be fully solved and is a source of much controversy and debate [4-5].

In broiler farms, the major issue is the loss of ammonia nitrogen mainly due to microbial degradation of uric acid laid in the litter with excretions [6]. Both the concentration and exposure time of birds to ammonia may have negative influence on the health of birds, such as tracheal irritation, eye damage, decreased feed efficiency and mortality [7-9]. Additionally, ammonia volatilizations reduce the value of poultry litter as a fertilizer due to nitrogen loss [10-11] and release malodorous substances into the atmosphere.

The current approaches to reduce ammonia emissions from poultry litter include physical, chemical or biological treatments [6]. Physical systems are expensive and technically complex to perform. Besides bio-filters and scrubbers, the most common practice for removing ammonia from broiler barns is by ventilation that exhausts to the atmosphere [7]. This practice has negative effects including increasing the contribution of poultry facilities to atmospheric pollution and environmental deposition which results in acidification of soil and water sources [11-12]. Chemical treatments are based on compounds (e.g., dry acids) that reduce $\mathrm{NH}_{3}$ emissions by lowering the $\mathrm{pH}$ of the litter and converting volatile $\mathrm{NH}_{3}$ into non-volatile ammonium $\left(\mathrm{NH}_{4}\right)$ [13]. However, this approach is highly invasive and reduces the overall use of poultry litter [14].

As an alternative to chemical approach, biological treatments, which include probiotic bacteria (PB), blends of enzymes, enzyme inhibitors and/or microorganisms, are increasingly used [15-17]. Augmenting feed, water or litter with biologicals enhances or alters the native microbial population with the aim of increasing $\mathrm{NH}_{3}$ degradation rates, preventing the formation of toxic compounds, improving the feed efficiency and/or competitively excluding undesirable microorganisms [18-19]. Moreover, many researchers have had success when using biological treatments to inhibit pathogens [20], reduce the effects of fungal toxins [21-22] and the incidence of Salmonella in litter from $52 \%$ to $13 \%$ [23].

The goal of this study was to evaluate the effect of probiotic bacteria (PB) in the reduction of ammonia emissions from a commercial farm in Veneto (northern Italy) during a summer production cycle. 


\section{Materials and methods}

\section{Experimental site and poultry facilities}

The purpose of the experimental research consists in the assessment of two facilities (Fig. 1), which are equal to each other due to their structural and plant systems, the numbers and genetic type of the animals, the feed formulation and the management practices during the production cycle. Litter, in both cases, is represented by pelleted straw $\left(1.5 \mathrm{~kg} \cdot \mathrm{m}^{-2}\right)$ distributed before the start of the production cycle.

Facility No.1 represents the experimental thesis including the treatment with the use of probiotic bacteria, whereas the second FacilityNo.2 serves as a comparison blank. Both facilities are $136 \mathrm{~m}$ long and $18 \mathrm{~m}$ wide with a net floor area of $2.447 \mathrm{~m}^{-2}$ for the animals. The feeding system is based on circular feeders for fodder and troughs for drinking water, in lines suitably spaced between them. An automatic balance system also allows monitoring and recording of the live weight of the animals.

The air inlet windows are present along the longitudinal walls at about $2.5 \mathrm{~m}$ from the floor, in number of 48-units on each side, equipped with an automated modular opening fin, each $0.88 \mathrm{~m}$ in length and $0.32 \mathrm{~m}$ in height. Two lines of nozzles for evaporative cooling are positioned above the windows.

The air is exchanged by forced ventilation using 13 axial fans in order to guarantee a maximum ventilation capacity of $36 \cdot 10^{4} \mathrm{~m}^{3} \cdot \mathrm{h}^{-1}: 10$ axial fans(diameter $1.38 \mathrm{~m}$ ), present in the distal wall and positioned at $1.0 \mathrm{~m}$ from the floor; 1 axial fan (diameter of $0.60 \mathrm{~m}$ ) inserted on the center line of the rear wall at $2.7 \mathrm{~m}$ from the floor; and 2 fans (diameter $1.09 \mathrm{~m}$ ) positioned at height of $2.7 \mathrm{~m}$ from the floor. The ventilation and cooling control system consist of a control unit that receives signals from 2 dry-bulb temperature sensors, 2 relative humidity probes and $2 \mathrm{CO}_{2}$ probes positioned within the facilities. All data are recorded every 2 minutes.

Moreover, the measurement of the ammonia concentration of both facilities was carried out every minute by means of probes (range 0-100 ppm), suitably calibrated, connected to an independent control unit.
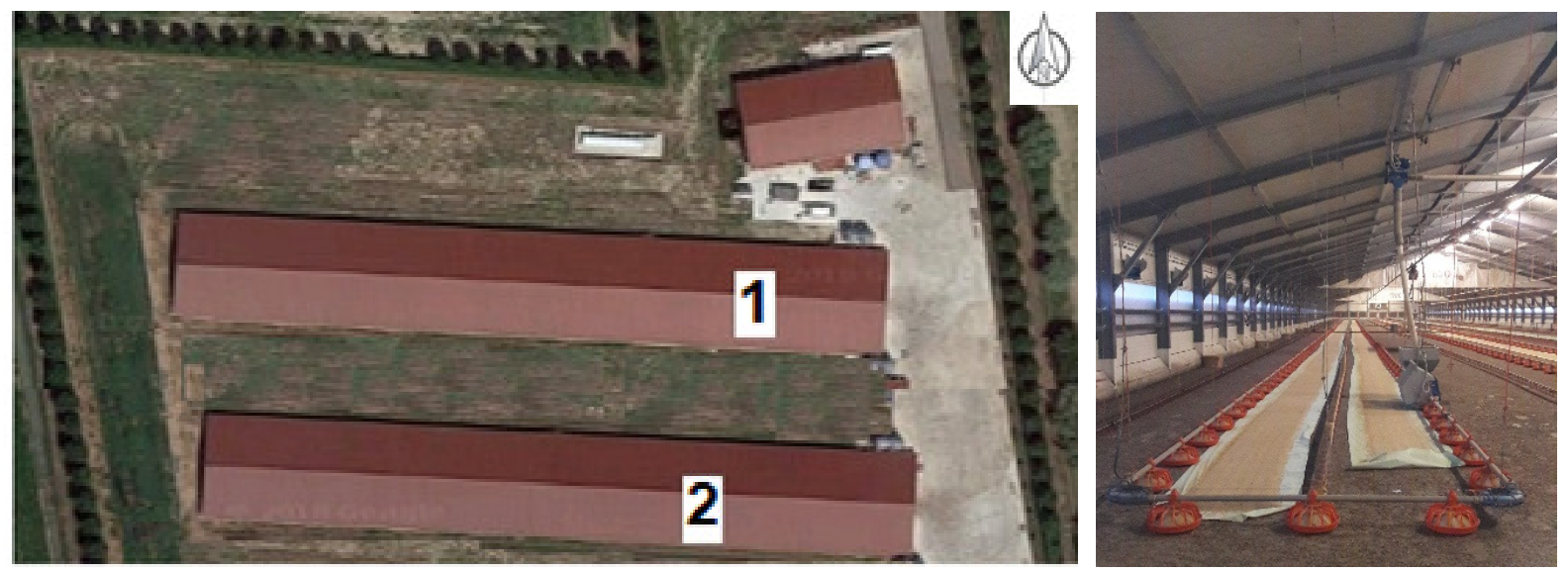

Fig. 1.Plan view of experimental site and poultry facilities

\section{Quantification of ammonia emissions}

The determination of the quantity of ammonia evaporated and expelled $\left(Q_{N H 3}\right)$ from the facilities during the production cycle occurred (expressed in $\mathrm{mg} \cdot \mathrm{h}^{-1}$ ), hourly, multiplying the ventilation air delivery rate $\left(Q_{V E N T}\right.$, expressed in $\left.\mathrm{m}^{3} \cdot \mathrm{h}^{-1}\right)$ by the concentration of ammonia $\left(K_{N H 3}\right.$, expressed in $\mathrm{mg} \cdot \mathrm{m}^{-3}$ ) detected in the breeding environment in the same period (1):

$$
Q_{N H 3}=Q_{V E N T} \times K_{N H 3},
$$

where $Q_{V E N T}$ - evaluated through the data acquired and recorded by the ventilation control system (every2 minutes)subsequently mediated to the hour unit (60 minutes) and finally transformed into air flow.

$K_{\mathrm{NH} 3}-$ obtained starting from the data, expressed in ppm ( vol $\left.\cdot \mathrm{vol}\right)$, recorded every minute by the control unit, subsequently averaged every hour (60 minutes) and transformed into $\mathrm{mg} \cdot \mathrm{m}^{-3}$ multiplying by $0.71 \mathrm{mg} \cdot \mathrm{m}^{-3}$. 
The quantities of ammonia expelled every hour from the facilities, added for each day of the production cycle from the time " 00 " to the time " 23 ", made it possible to calculate the daily quantity expelled from each barn $\left(\mathrm{QNH}_{3} \cdot \mathrm{day}^{-1}\right)$. The total amount of ammonia expelled from every facility during an entire production cycle is obtained by adding up the daily quantities $\left(\mathrm{QNH}_{3} \cdot \mathrm{cycle}^{-1}\right)$.

\section{Probiotic bacteria treatment}

The treatment with probiotic bacteria (Facility No.1) was carried out in 3 times during the production cycle:

- as before the distribution of the litter (day 0),

- after 15-days of production cycle,

- after 35-days of production cycle.

The experimental product containing probiotic bacteria, in powder form, had a $\mathrm{pH}$ range of 6.87.0 and a humidity range of 4-5\%.Further details regarding the quantities used and the composition cannot be examined in detail for reasons linked to industrial secrecy.

\section{Results and discussions}

Ammonia emission trends

The results of the comparison are reported in Fig.2. Despite the longer duration ofthe production cycle with probiotic bacteria treatment (49-days) than control (47-days), the quantity of expelled ammonia was found to be about $36 \%$ lower at the end of the cycle. From Figure 2 it is possible to observe how the effects of the probiotic treatment have been activated, in particular, in the second half of the production cycle (after the $20^{\text {th }}$ day).The first 20-days of the production cycle, most likely others to have smaller amounts of ammonia, were found to be necessary to activate the biological processes of the experimental treatment.

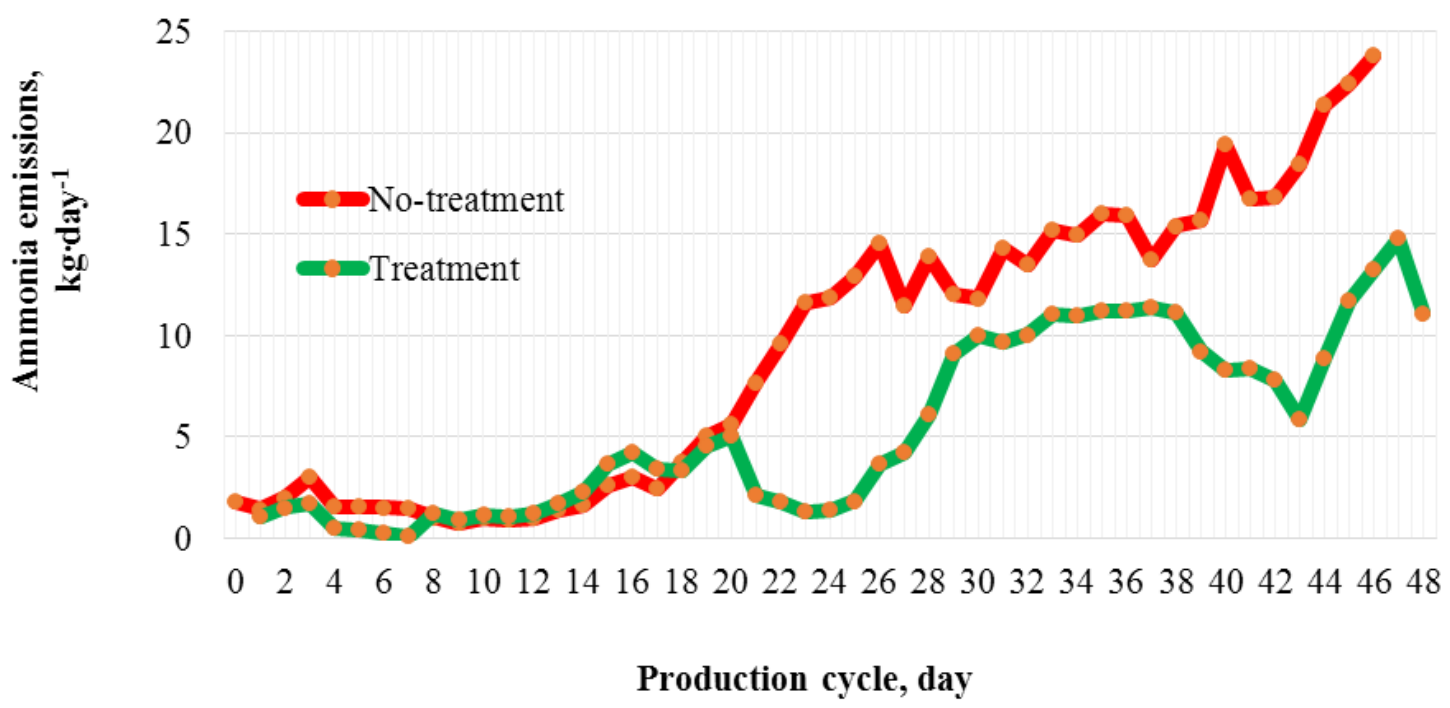

Fig. 2. Daily total ammonia emissions by Facility No. 1 (Treatment) and 2 (No-treatment) during summer production cycle

\section{Livestock parameters and emissions efficiency}

In addition to the important reduction of ammonia in the facility treated with probiotic bacteria compared to the untreated control $\left(-157.7 \mathrm{~kg} \cdot \mathrm{cycle}^{-1}\right)$, significant benefits were also observed in terms of reduction in the mortality rate and an increase in the live weight of animals at the end of the cycle (Table 1).

Regarding the poultry mortality rate, despite the initial number of animals inserted in the two facilities, it differed by 80 units in favour of the untreated control, however, at the end of the production cycle this difference was attenuated to 3 units.

With regard to the greater increase of the live weight of the animals at the end of the production cycle, this aspect is found to be overall higher in the facility treated with probiotic bacteria of approximately $4.518 \mathrm{~kg}$. 
Animal parameters and emission factors during the summer production cycle

\begin{tabular}{|l|c|c|}
\hline \multicolumn{1}{|c|}{ Parameters } & $\begin{array}{c}\text { Facility No.1 } \\
\text { (Treatment) }\end{array}$ & $\begin{array}{c}\text { Facility No.2 } \\
\text { (No-Treatment) }\end{array}$ \\
\hline Initial number of poultry, day 1 & 41.920 & 42.000 \\
\hline Final number of poultry, final day & 39.617 & 39.620 \\
\hline Poultry live weight, kg & 101.365 & 96.847 \\
\hline Total ammonia emission, kg & 277.9 & 435.6 \\
\hline \multicolumn{2}{|l}{} \\
\hline Emission factor & 0.007 & 0.011 \\
\hline For animal sold, $\mathrm{kgNH}_{3}$ per animal & 0.03 & 0.004 \\
\hline For kg of live weight sold, $\mathrm{kgNH}_{3}$ per animal &
\end{tabular}

Finally, therefore, it emerges that the rate of emissions both per unit of animal (0.007 vs $0.011 \mathrm{kgNH}_{3} \cdot$ animal $^{\circ}$ cycle $\left.^{-1}\right)$ and for live weight of the animals $\left(0.003 \mathrm{vs} 0.004 \mathrm{kgNH}_{3} \cdot\right.$ animal $^{\circ}$ cycle $\left.^{-1}\right)$ is greater in the untreated control than inthe facility treated with probiotic bacteria.

\section{Conclusions}

1. In the present paper probiotic bacteria (PB) is studied and proposed as a non-invasive technique for the reduction of ammonia emissions in a commercial poultry farm during a summer production cycle.

2. Preliminary results obtained from the use of $\mathrm{PB}$ in the litter have shown a reduction of ammonia emissions of at least $35 \%$ compared to a comparison thesis, without treatment.

3. Considering the possibility of being able to perform at least 4-5 production cycles per year, this reduction is very important both in environmental terms and in legislative terms to reduce the zootechnical load at the farm level.

4. The next objectives of the research foresee the monitoring of other production cycles in different seasons in order to assess whether the efficiency of these bacteria and the consequent reduction of ammonia emissions may be affected by the climate component.

\section{References}

[1] Herrero M., Gerber P., Vellinga T., Garnett T., Leip A., Opio C., Montgomery H.,Livestock and greenhouse gas emissions: The importance of getting the numbers right. Animal Feed Science and Technology, vol. 166, 2011, pp. 779-782.

[2] Redwine J.S., Lacey R.E., Mukhtar S., Carey J. B., Concentration and emissions of ammonia and particulate matter in tunnel-ventilated broiler houses under summer conditions in Texas. Transactions of the ASAE, vol. 45(4), 2002, pp.1101.

[3] Wei S., Bai Z.H., Chadwick D., Hou Y., Qin W., Zhao Z.Q., Ma, L., Greenhouse gas and ammonia emissions and mitigation options from livestock production in peri-urban agriculture: Beijing-A case study. Journal of Cleaner Production, vol. 178, 2018, pp. 515-525.

[4] Sommer S.G., Olesen J.E., Petersen S.O., Weisbjerg M.R., Valli L., Rodhe L., Béline F., Region $\square$ specific assessment of greenhouse gas mitigation with different manure management strategies in four agroecological zones. Global Change Biology, vol. 15(12), 2009, pp. 2825-2837.

[5] Coufal C.D., Chavez C., Niemeyer P.R., Carey J. B. Nitrogen emissions from broilers measured by mass balance over eighteen consecutive flocks. Poultry science, vol. 85(3), 2006, pp. 384-391.

[6] Cook K. L., Rothrock, M.J., Eiteman M.A., Lovanh N.,Sistani K., Evaluation of nitrogen retention and microbial populations in poultry litter treated with chemical, biological or adsorbent amendments. Journal of Environmental Management, vol. 92(7), 2011, pp. 1760-1766.

[7] Ritz C.W., Fairchild B.D., Lack M.P.,Implications of ammonia production and emissions from commercial poultry facilities: a review. Journal of Applied Poultry Research,vol. 13, 2004, pp. 684-692.

[8] Webb J., Broomfield M., Jones S., Donovan B., Ammonia and odour emissions from UK pig farms and nitrogen leaching from outdoor pig production. A review. Scienceof Total Environment,vol. 470-471, 2014, pp. 865-875. 
[9] Cockburn A., Brambilla G., Fernandez M., Arcella D., Bordajandi L.R., Cottrill B., van Peteghem C., Dorne J., Nitrite in feed: from animal health to human health. Toxicology and Applied Pharmacology,vol. 270, 2013, pp. 209-217.

[10] Nuernberg G.B., Moreira M.A., Ernani P.R., Almeida, J.A.,Maciel, T.M., Efficiency of basalt zeolite and Cuban zeolite to adsorb ammonia released from poultry litter. Journal of Environmental Management, vol. 183, 2016, pp. 667-672.

[11] McCrory D.F., Hobbs P.J., Additives to reduce ammonia and odor emissions from livestock wastes: a review. Journal of Environmental Quality,vol. 30, 2001, pp. 345-355.

[12] Shah S.B., Baird C.L., Rice J.M., Effect of a metabolic stimulant on ammonia volatilization from broiler litter. Journal of Applied Poultry Research,vol. 16, 2007, pp. 240-247.

[13] Moore P.A., Daniel T.C., Edwards D.R.,Miller, D.M., Evaluation of chemical amendments to reduce ammonia volatilization from poultry litter. Poultry Science, vol. 75(3), 1996, pp. 315-320.

[14] Dornelas K.C., Schneider R.M., Do Amaral, A.G., Biogas from poultry waste - production and energy potential. Environmental monitoring and assessment, vol. 189(8), 2017, pp. 407.

[15] Choi I.H.,Moore P.A., Effect of various litter amendments on ammonia volatilization and nitrogen content of poultry litter. Journal of Applied Poultry Research, vol. 17(4), 2008, pp. 454-462.

[16] Ghadban G.S., Probiotics in broiler production-a review. Archiv fur Geflugelkunde, vol. 66(2), 2002, pp. 49-58.

[17] Saeed M., Arain M.A., Naveed M., Alagawany M., El-Hack M.E.A., Bhutto Z.A., Chao S., Yucca schidigera can mitigate ammonia emissions from manure and promote poultry health and production. Environmental Science and Pollution Research, 2018, pp. 1-7.

[18] Naseem S., King A.J., Ammonia production in poultry houses can affect health of humans, birds, and the environment-techniques for its reduction during poultry production. Environmental Science and Pollution Research, vol. 25, 2018, pp. 15269-15293.

[19] Ibrahim R.R., Khalil F., Mostafa A.S., Emeash H.H., Efficacy of Probiotic in Improving Welfare and Mitigating Overcrowding Stress in Broilers. Journal of Advanced Veterinary Research, vol. 8(4), 2018, pp. 73-78.

[20] Cole K., Farnell M.B., Donoghue A.M., Stern N.J., Svetoch E.A., Eruslanov B.N., Volodina L.I., Kovalev Y.N., Perelygin V.V., Mitsevich E.V., Mitsevich I.P., Levchuk V.P., Pokhilenko V.D., Borzenkov V.N., Svetoch O.E., Kudryavtseva T.Y., Reyes-Herrera I., Blore P.J., Solis De Los Santos F., Donoghue D.J., Bacteriocins reduce Campylobacter colonization and alter gut morphology in turkeypoults. Poultry Science,vol. 85, 2006, pp. 1570-1575.

[21] Awad W.A., Böhm J., Razzazi-Fazeli E., Ghareeb K., Zentek J.,Effect of addition of a probiotic microorganism to broiler diets contaminated with deoxynivalenol on performance and histological alterations of intestinal villi of broiler chickens. Poultry Science,vol. 85, 2006, pp. 974-979.

[22] Chiang S. H.,Hsiem W.M., Effect of direct feed microorganisms on broiler growth performance and litter ammonia level. Asian-Australian Journal of Animal Science,vol. 8, 1995, pp. 159-162.

[23] Salim H.M., Patterson P.H., Ricke, S.C., Kim, W.K., Enhancement of microbial nitrification to reduce ammonia emission from poultry manure: a review. World's Poultry Science Journal, vol. 70(4), 2014, pp. 839-856. 